\title{
Rehabilitation of the disabled adolescent: experience with a local authority assessment centre
}

\author{
P NEWTON, D R SWINSON, K BRUCE
}

\begin{abstract}
School leavers and young adults who are severely physically disabled pose particular problems for habilitation and rehabilitation. A local authority unit, the Fourways Assessment Centre, has been providing a comprehensive service to this group of people for the past 10 years. Rather than operating as an independent self contained unit it has been closely integrated with the local authority social services and educational services.
\end{abstract}

\section{Introduction}

The problems of the young physically disabled have received much more attention in recent years than previously.' In particular, there have been increased opportunities for vocational training and further education. Long term custodial care is now regarded as unacceptable for all but a small minority of severely disabled adolescents, the emphasis instead being on supporting the individual in his own home with the requisite social services and community health services. The severely disabled adolescent needs not only medical rehabilitation and vocational training but also help with further education and achieving psychological independence. The less severely disabled person can often use his local social services effectively. For those with more severe handicap there is little organised local authority provision for their requirements. ${ }^{23}$ In

Wrightington Hospital, Wigan, Lancs WN6 9EP

P NEWTON, MRCP, senior registrar in rheumatology and rehabilitation D R SWINSON, FRCP, consultant in rheumatology and rehabilitation

Fourways Assessment Centre, Tyldesley, Lancs

K BRUCE, DIPED, principal

Correspondence to: Dr P Newton. consequence, they experience great difficulties in adjusting to life after school, and their employment prospects are poor. ${ }^{4}$

The institutions that provide rehabilitation and education for young people mostly operate on a national basis and are run by charitable bodies. Usually, they have no links with local education and social service departments, and they tend to provide either for a specific type of disability (for example, cerebral palsy, blindness) or for a specific purpose (for example, training in light industry). Not all such institutions accept the severely disabled.

The Fourways Assessment Centre in the Wigan metropolitan borough was created in the early 1970s as a radical departure from this traditional type of unit. It was developed to cater for the local community's own severely handicapped school leavers and newly handicapped young adults. At that time in the special schools there were more physically handicapped children than usual, mainly as a result of changes in the medical management of spina bifida. It was hoped to avoid long term residential care for these children when they reached adult life by placing more emphasis on their rehabilitation in the community.

\section{Experience}

ORGANISATION

The two buildings used for the centre comprise a hostel (most students being resident through the week but not at weekends), an assessment flat, a dining room, teaching rooms, administrative offices, and a laundry, which operates on a commercial basis and provides employment for some exstudents. Staffing is provided by the social service department (fig 1), the district health authority (table I), and the education department. In the last instance teachers are provided by Leigh College for classes held at the assessment centre; students may also attend the college for further education.

Up to the end of 1983,106 students were either currently resident or had completed a period at the unit. Sixty eight per cent came from physically handicapped schools in the district, suitable school leavers being automatically considered for admission; the remainder were referred from social 
service departments (19\%) or from medical rehabilitation units (13\%). The centre is willing to take students from anywhere in the country, but $70 \%$ came from the local (Wigan) metropolitan borough and most of the remainder from adjacent local authorities.

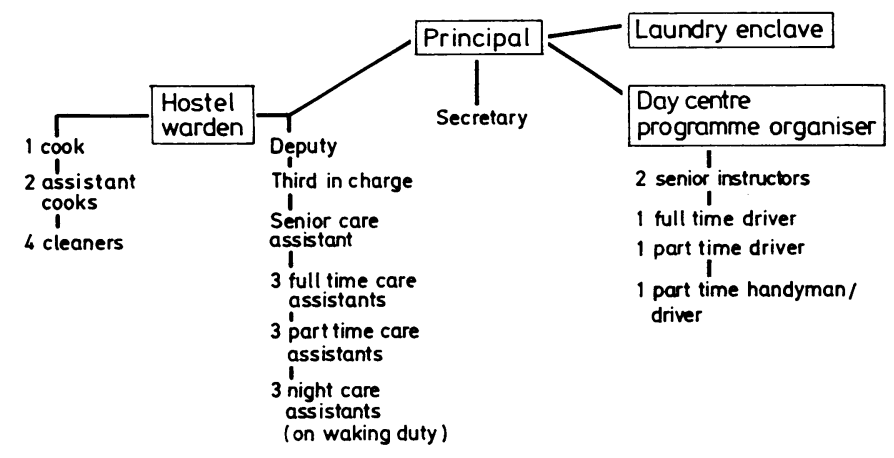

FIG 1-Staffing provided by social services department.

TABLE I-Staffing provided by the district health authority

\begin{tabular}{ll}
\hline & Workload \\
\hline Consultant in rehabilitation & Visits as necessary \\
Nursing sister & Full time \\
Physiotherapist & 1 session a week \\
Occupational therapist & 2 sessions a week \\
General practitioner & Primary medical care as required \\
& \\
\hline
\end{tabular}

\section{MEDICAL DIAGNOSES}

Table II shows the medical conditions encountered. Some students had more than one medical problem. Cerebral palsy and spina bifida were the most common handicaps, though trauma in later childhood and adolescence was also an important cause of handicap.

TABLE II-Medical problems

\begin{tabular}{lcc}
\hline Diagnosis & $\begin{array}{c}\text { No of } \\
\text { students }^{*}\end{array}$ & $\begin{array}{c}\text { Mean duration of } \\
\text { stay (months) }\end{array}$ \\
\hline Spina bifida & 30 & 24 \\
Cerebral palsy & 28 & 16 \\
Epilepsy & 14 & 14 \\
Head injury & 12 & 14 \\
Congenital musculoskeletal conditions & 10 & 19 \\
Spinal injury & 7 & 17 \\
Visual impairment & 7 & 19 \\
Hearing impairment & 6 & 25 \\
Muscular dystrophy & 5 & \\
Infection of the central nervous system & 4 & \\
Hydrocephalus & 4 & \\
Tumour of the central nervous system & 2 & \\
Juvenile arthritis & 1 & \\
Chronic renal failure & 1 & \\
Burns & 1 & \\
Psychiatric conditions & 1 & \\
* Total number 112 (including 6 day students). & \\
t Total mean length of stay 18.5(range 2-49) months. & \\
&
\end{tabular}

DURATION OF STAY

Although the intention is to admit young people for about two years, the length of stay varied appreciably according to the medical diagnosis. In particular, the multiple physical problems of adolescents with spina bifida resulted in a mean length of stay of 24 months compared with the total mean of 18.5 months. A further factor is the duration of educational courses at the local tertiary college, which may last for three or four years and necessitate the student staying at the centre for this period. A small number of young people were admitted for a short period only, usually because further assessment after admission suggested that they were unlikely to derive much benefit by staying longer.

\section{AGE RANGE}

Table III shows the ages on admission of the residents, the vast majority $(92 \%)$ being in the $16-25$ age group.

\section{NON-ADMISSIONS}

Twenty nine subjects were considered for admission to the centre but were not subsequently admitted; table IV shows their diagnoser. There was no notable difference in diagnosis between those admitted and those not, with the exception of severe psychiatric problems, for which the centre is not able to cope. Table $\mathrm{V}$ shows the actual reasons for non-admission, the most common being that the subject him or herself decided on alternative means of help. The unit does not provide for the severely mentally subnormal and is reluctant to admit young people with an intelligence quotient of under 70 . Furthermore, it does not aim at providing long term residential care, and those who require this are referred elsewhere. The fees are high, and in several cases other local authorities were not prepared to finance their students. Only one student was turned down because of physical disability; in this case the problem was previously unrecognised congenital heart disease.

TABLE III-Age on admission $(n=81)$
\begin{tabular}{lcccc}
\hline Age (years): & $16-20$ & $21-25$ & $26-30$ & $31-35$ \\
\hline$\%$ of residents: & 80 & 12 & 4 & 4 \\
\hline
\end{tabular}

\begin{tabular}{lc}
$\begin{array}{l}\text { TABLE IV-Medical problems } \\
\text { admitted to the centre }(n=29)\end{array}$ & students \\
& not \\
\hline Diagnosis & $\begin{array}{c}\text { No of } \\
\text { subjects }\end{array}$ \\
\hline Cerebral palsy & 8 \\
Epilepsy & 5 \\
Head injury & 4 \\
Cardiac disease & 3 \\
Psychiatric disease & 3 \\
Spinal injury & 2 \\
Congenital musculoskeletal disease & 2 \\
Hearing impairment & 2 \\
Juvenile arthritis & 2 \\
Brain tumour & 2 \\
Spina bifida & 1 \\
Infection of the central nervous system & 1 \\
Hydrocephalus & 1 \\
Muscular dystrophy & 1 \\
Demyelinating disease & 1 \\
\hline
\end{tabular}

TABLE V-Reasons for non-admission $(n=29)$

\begin{tabular}{lc}
\hline Reason & $\begin{array}{c}\text { No of } \\
\text { subjects }\end{array}$ \\
\hline Student declined & 8 \\
Low intelligence & 7 \\
Psychiatric behavioural problem & 5 \\
Long term care needed & 4 \\
Local authority finance needed & 3 \\
Insufficient disability & 3 \\
Severe physical illness & 1 \\
\hline
\end{tabular}

TABLE VI-Residential situation of 89 students before admission and after discharge. Figures are numbers (\%)

\begin{tabular}{lcr}
\hline & $\begin{array}{c}\text { Before } \\
\text { admission }\end{array}$ & $\begin{array}{c}\text { After } \\
\text { discharge }\end{array}$ \\
\hline Hospitals/residential care & $13(15)$ & $9(10)$ \\
Families & $75(84)$ & $60(67)$ \\
Independent & $1(1)$ & $20(22)$ \\
\hline
\end{tabular}

\section{OUTCOME}

Table VI shows the residential situation of 89 young people who left the centre. There was a pronounced trend towards increasing independence after their stay, and the need for residential care was reduced. A comparison of activities of daily living assessments of students on admission and discharge show a pronounced improvement in such activities as dressing and bathing (fig 2). Not surprisingly, in a group of severely handicapped young people a large proportion still depend, to some extent, on social service provisions; $48 \%$ of students still needed to attend a social service day centre (table VII). In view of the very poor local employment opportunities it is notable that $18 \%$ of ex-students gained regular work and $12 \%$ were in further education. At least 13 were known to be married. 
There were seven deaths in the group; three students had muscular dystrophy, two cerebral tumours, and one each spina bifida and spinal iniury.

\section{POTENTIAL DEMAND FOR ADOLESCENT REHABILITATION}

Sixteen of the 24 places were used by residents of the Wigan borough, which has a population of 310000 . For the most recent period available-
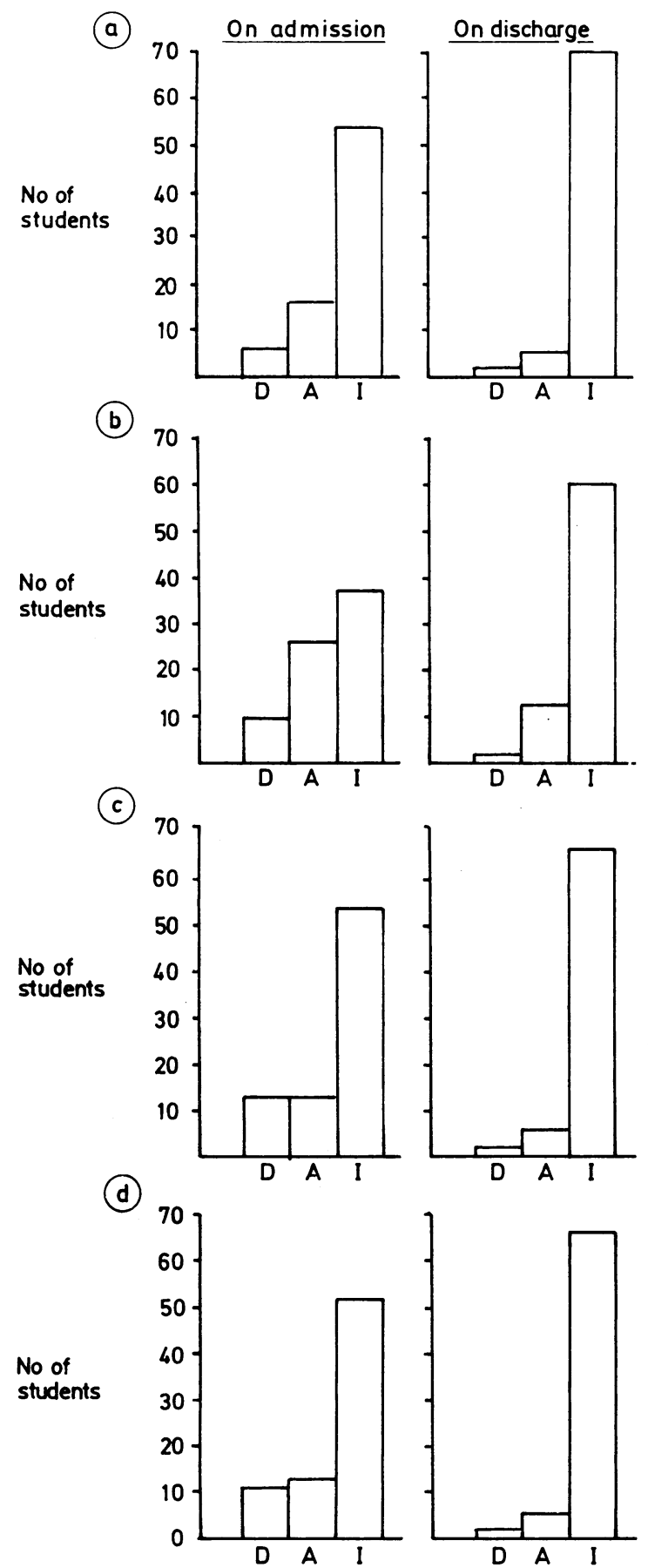

FIG 2-Improvement in ability to (a) dress, (b) bath, (c) manage bladder function, and (d) manage bowel function of 89 students at discharge. $\mathrm{D}=$ totally dependent on others; $\mathrm{A}=$ needs assistance; $\mathrm{I}=$ independent.

1980,1981 , and 1982 (three years) - of the 20 school leavers from the special school for the physically handicapped in Wigan, 11 were accommodated in the centre, averaging nearly four each year. For births in the decade 1971-80 the local handicap register shows a steady decline in the number of new cases of spina bifida and cerebral palsy, and it is therefore likely that even fewer students with these conditions will need this service in the 1990s. costs

The estimated costs of running the centre in 1984 (table VIII) were about $£ 300000$ - that is, $£ 12500$ per place per year, of which over half is devoted to staff salaries.

TABLE VII-Daily occupation after leaving centre of 89 students

\begin{tabular}{lcl}
\hline Occupation & No $(\%)$ & Further details \\
\hline In employment & $16(18)$ & $\begin{array}{l}\text { 6 married } \\
\text { Further education }\end{array}$ \\
$\begin{array}{l}11(12) \\
\text { At home }\end{array}$ & $19(21)$ & $\begin{array}{c}\text { 5 married } \\
\text { day centre placements or } \\
\text { seeking employment }\end{array}$ \\
At social services day centres & $43(48)$ &
\end{tabular}

\begin{tabular}{lr}
\multicolumn{1}{l}{ TABLE VIII-Estimated costs $(1984)$} \\
\hline & \multicolumn{1}{c}{ Cost } \\
\hline Staff wages & $£ 168000$ \\
General running & $£ 81000$ \\
Maintenance & $£ 22000$ \\
Debt and interest & $£ 28000$ \\
\hline Total & $£ 299000$
\end{tabular}

\section{Discussion}

The problems of the disabled adolescent have received little attention until recently in this country, although several reports have drawn attention to the overall lack of provision. ${ }^{1.35}$ There has been more interest shown in the United States, particularly in relation to education, vocational training, and the psychological difficulties of this group. ${ }^{6-9}$ Although the Warnock report in 1978 recommended improved further education and vocational training, ${ }^{10}$ the opportunities for the severely physically disabled are still limited. They have multiple interrelated problems, which include the need for continuing medical treatment and rehabilitation, low educational attainment, little chance of gaining paud employment, and delayed emotional and psychological development. None of these problems can be tackled in isolation, and there is a great need for locally based units that offer a comprehensive approach for these people.

Further education colleges will now take disabled students much more willingly than before, though a recent review still noted that the facilities for the severely disabled were limited. ${ }^{\text {" }}$ As a group they are particularly in need of further education since they usually lag some way behind their ablebodied counterparts.

Obtaining paid employment is, obviously, an ideal for any young person, but presents considerable difficulties at the moment. Some disabled will never be employable on the open market, although sheltered work is a possibility for many. Nevertheless, they have a right to expect efforts to be made to find them suitable employment, ${ }^{12}$ and schemes can be devised that show good cost effective benefits. ${ }^{8}$

From the point of view of medical rehabilitation, disabled youngsters are usually well served as children but their problems do not simply end when they leave the care of a paediatrician. It is, therefore, important that they are assessed by a physician interested in adult rehabilitation at around the age of 16 . With the overall shortage of physicians interested in rehabilitation it is likely that only a small proportion of disabled young people are assessed in this way, and, consequently, many who could become physically independent do not have the opportunity to do so. The need of the handicapped adolescent to become emotionally independent of his or her parents is an aspect to which little attention has been paid, though it may present particular problems. ${ }^{7}$ Although it would be physically practicable for many of its students to travel to the centre each day, a period of weekday residence was considered to be absolutely essential for the psychological development of the individual. The situation may also be complicated by the sizable financial contribution that is made to the household budget of the student's family by disablement associated benefits. 
A further feature of an institution like Fourways is that it becomes a point of contact with the rehabilitation services for its students and past students. The Warnock committee suggested that each disabled teenager on leaving school should be given a "named person" contact to help him in obtaining the right sort of help. ${ }^{10}$ As far as we know, this suggestion has not been formally developed, but the staff at the centre have found themselves taking on this role, and it has become an important source of help for previous students.

It is difficult to quantify the benefits of any particular rehabilitation programme or institution. We have provided evidence for the increased physical independence, improved job prospects, and low requirement for long term residential accommodation of students leaving the unit. It seems unlikely that these benefits would have occurred if no specific help had been offered to them. In view of the expense of running such an institution, however, alternative and possibly cheaper programmes should be considered. Provision can be made for pupils to stay on at special schools until the age of 19 . From the local experience, this would benefit education and vocational training, but it seems unlikely that personal independence and psychological maturity would be much improved. The other alternative would be to improve already existing community services and to coordinate them more effectively. To a large extent this has already happened with the development of the centre, which has the additional benefit of including a residential hostel. A third course would be for the local authority to use the national charitable institutions already in existence for those adolescents needing a period away from home. This is certainly necessary for many individuals with specific problems (for example, blindness, deafness) that require highly specialised teaching and training.

The data collected from the centre can also provide information on the potential demand for this type of unit. The borough of Wigan has a population of 310000 , of which about four school leavers each year may require admission. In addition, up to four newly disabled young adults annually may also benefit. If the mean stay is assumed to be 18 months then as few as 12 places would meet most of the needs of the borough; if it is assumed to be two years then 16 places would be adequate. Since it is unlikely that a centre of less than 24 beds would be viable ideally a catchment population of at least 600000 would be needed to support it on the basis of one place per 25000 population. It is for this reason that the centre currently accepts students from adjacent local authorities. For reasons already stated, there is likely to be a reduced demand from certain groups (spina bifida and cerebral palsy) in the next decade, and the norm of one place per 25000 population may be an overestimate of future demand.

Although the difficulties of the young severely physically handicapped are complex, they do not represent a numerically very great problem, and previous studies already referred to have shown that they are not intractable. Very few young people should now require long stay residential accommodation, and the quality of life can be improved for many. We believe that the type of institution we have described here can serve as a basis for future improvements.

We thank Sister Mather for contributing her detailed knowledge of the students.

\section{References}

1 Gloag D. The dynamic approach to residential care of the disabled. Br Med $\mathcal{J}$ 1984;288:1323-4. 2 Chamberlain MA. The handicapped school-leaver. Arch Dis Child 1981;56:737-8.

3 Anonymous. Handicapped school leavers [Editorial]. Lancet 1976;i:77.

4 Hirst MA. Young people with disabilities: what happens after 16? Child Care Health Dev 1983;9:273-84.

5 Gloag D. Caring for the young disabled. Br Med $\mathcal{F} 1983 ; 286: 1376$

6 Goldberg RT, Johnson BD. A comparative study of five groups of handicapped children in Goldberg RT, Johnson BD. A comparative study of five groups
vocational rehabilitation. Scand f Rehabil Med 1978;10:215-20.

7 Goldberg RT. Towards an understanding of the rehabilitation of the disabled adolescent. Rehabil Lit 1981;42:66-74.

8 Wehman P, Hill JW. Competitive emplovment for moderately and severely handicapped individuals. Except Child 1981;47:338-45

9 Abramson M, Ash MJ, Nash WR. Handicapped adolescence-a time for reflection. Adolescence 1979;14:557-65.

10 Committee of enquiry into the education of handicapped children and young people. Special educational needs. London: HMSO, 1978 (Cmnd 7212.) (Warnock report.)

11 Bradley J, Hegarty S. Sixteen and what next? Spec Educ Forward Trends 1982;9:9-12.

12 Chamberlain MA. Work for the disabled. Br Med f 1984;289:639-40.

(Accepted 16 May 1985)
A middle aged man had a vasectomy during his first marriage. He remarried and had a reversal operation that has proved unsuccessful in achieving a pregnancy. What treatment is advised?

The quality of semen produced after a technically successful reversal of vasectomy is unpredictable. The interval between the original vasectomy and subsequent reversal is important as the longer the interval then the poorer the resultant sperm count is likely to be. ${ }^{\prime}$ Few pregnancies are achieved when the interval is greater than 10 years. The age of the patient is also relevant as semen quality declines with age. It is unlikely that the original spermatogenic potential of the testes is ever fully restored after reversal of vasectomy, although often this is sufficiently good to achieve pregnancy. Antisperm antibodies often develop after vasectomy ${ }^{2}$ and after reversal these may result in agglutination or immobilisation of the sperm. ${ }^{3}$ Steroid treatment may prove to be successful in lowering the antibody titre and achieving pregnancy. ${ }^{4}-\mathrm{J}$ C GINGELL, consultant urologist and lecturer in urology, Bristol.

1 Silber SJ, Galle, J, Friend D. Microscopic vaso-vasostomy and spermatogenesis. $\mathcal{J}$ Uro 1977;117:299-302.

2 Rumke P. Autoantibodies against spermatozoa. In: Cohen J, Hendry WF, eds. Spermatozoo, antibodies and infertility. Oxford: Blackwell Scientific, 1978:67-79.

3 Royle MG, Parslow JM, Kingscott MMB, Wallace DMA, Hendry WF. Reversal of vasectomy: the effects of sperm antibodies on subsequent fertility. Br $\mathcal{Y}$ Urol 1981;53:654-9.

4 Hendry WF, Morgan H, Stedronska J. The clinical significance of antisperm antibodies in male subfertility. Brf U Urol 1977;49:757-62.
surat

5 Shulman S, Mininberg DT, Davis JE. Significant immunologic factors in male infertility. $\mathcal{f}$ Urol 1978;119:231-4.

Workers on roof insulation find that full industrial masks are intolerable in the hot close confines of roof spaces and wear simple surgical masks. They suffer in many cases from persistent and recurrent sore throats, and even brief exposure with or without a face mask produces $a$ dry and sore throat with an irritating cough, the former lasting for hours after exposure. What are the chances of there being a late onset hazard, as yet as unrecognised as that which followed years of unsuspecting exposure to asbestos dust?

Most roof insulation in the United Kingdom is glass fibre, generally made from borosilicate or calcioalumina silicate. The mean fibre diameter is about $6 \mu \mathrm{m}$, but $5-10 \%$ of fibres may be respirable. ${ }^{1}$ Recently reported epidemiological studies of groups occupationally exposed to glass fibre during its manufacture showed some excess of lung cancer. ${ }^{23}$ In one the excess in workers manufacturing rock wool reached "statistical significance," but some had had previous occupational exposure to asbestos. ${ }^{3}$ Neither study, however, included controls for cigarette smoking. Men who install glass fibre insulation material are probably not exposed to a higher concentration of respirable fibres than those employed in the manufacturing industry $(<1$ fibre $/ \mathrm{ml}) .{ }^{4}$ Installation workers, however, may be exposed to mean total dust concentrations of $35 \mathrm{mg} / \mathrm{m}^{3}$ or more ${ }^{4}$ : as the recommended exposure limit for "nuisance dust" is $10 \mathrm{mg} / \mathrm{m}^{3}$ in the United Kingdom ${ }^{4}$ some form of respirator protection will usually be necessary. Although there is no clear evidence of long term ill effects in man, glass fibre is known to cause acute irritation of the skin, eyes, and respiratory tract. This is often troublesome and will be compounded by the heat, low humidity, and general dustiness of confined roof spaces. In such circumstances oronasal canister masks are poorly tolerated and simple surgical masks are ineffective. Workers who are regularly exposed may be provided with equipment such as Airstream helmets or Dustmaster soft hats, which afford facial cooling as well as respiratory and ocular protection.-W R LEE and A R SCOTT, professor and lecturer in occupational health, Manchester.

1 Hill JW. Man-made mineral fibres. F Soc Occup Med 1978;28:134-41.

2 Shannon HS, Hayes M, Julian JA, Muir DCF. Mortality experience of glass fibre workers. Br $f$ Ind Med 1984;41:35-8.

3 Sarracci R, Simonata L, Acheson ED, et al. Mortality and incidence of cancer of workers in the man-made vitreous fibres producing industry: an international investigation at 13 European plants. Br F Ind Med 1984;41:425-36.

4 Health and Safety Commission. Man-made mineral fibres: discussion document. HMSO: London, 1979:7. 